\title{
In-Situ Observations on the Fracture Mechanism of Diffusion-Alloyed Ni-Containing Powder Metal Steels and a Proposed Method for Tensile Strength Improvement
}

\begin{abstract}
M.W. WU, K.S. HWANG, and H.S. HUANG
The mechanical properties of Ni-containing powder metal (PM) steels are usually inferior to those of their wrought counterparts. The main problem is attributed to the non-uniform $\mathrm{Ni}$ distribution, in addition to the problems caused by porosity. The effects of this non-uniform alloying on the mechanical properties were investigated in this study using mini tensile bars that were made of diffusion-alloyed FD-0405 (Fe-4Ni-1.5Cu-0.5Mo-0.5C) powders. In-situ observations under a scanning electron microscope (SEM) were carried out during the tensile testing. The results indicated that the soft Ni-rich/C-lean area around the pore, which was identified as ferrite using electron backscattered diffraction (EBSD) analysis, was responsible for the failures. By adding $\mathrm{Cr}$ in the form of prealloyed powders, the distribution of $\mathrm{Ni}$ and $\mathrm{C}$ became more uniform, and the Ni-rich/C-lean ferrite was replaced by bainite and martensite. After sintering at $1250{ }^{\circ} \mathrm{C}$ for 1 hour, the tensile strength of the Fe-4Ni-1.5Cr- $0.2 \mathrm{Mo}-0.5 \mathrm{C}$ and $\mathrm{Fe}-4 \mathrm{Ni}-3 \mathrm{Cr}-$ $0.5 \mathrm{Mo}-0.5 \mathrm{C}$ reached 1178 and $1323 \mathrm{MPa}$, respectively, without employing any accelerated cooling system. These properties are higher than all those reported to date in the literature for sinter-hardened PM alloys that were rapidly cooled after sintering. This significant improvement was attributed to the homogeneous alloying, particularly due to the reduction of the repelling effect between $\mathrm{Ni}$ and $\mathrm{C}$, as was explained through the thermodynamics analysis using the Thermo-Calc program.
\end{abstract}

DOI: $10.1007 / \mathrm{s} 11661-007-9201-y$

(C) The Minerals, Metals \& Materials Society and ASM International 2007

\section{INTRODUCTION}

THE mechanical properties of conventional pressedand-sintered parts are usually poor compared to those of their wrought counterparts. One of the main problems is that large numbers of pores are present in the microstructure. The shapes, sizes, and numbers of pores are critical in determining the final mechanical properties. $^{[1-6]}$ The other problem is that most alloying elements are not homogenized. This is partly due to the inadequate powder mixing, to powder segregation during shipping and handling, and to the slow dissolution rate of the powder into the iron matrix, particularly in the case of $\mathrm{Ni}$, which has a slow diffusion rate compared to the other main alloying elements such as $\mathrm{C}$, $\mathrm{Cu}$, and Mo. The resulting inhomogeneous microstructures, particularly those around sintered necks and pores, thus impair the final mechanical properties. ${ }^{[7,8,9]}$

An intuitive approach to solving the homogenization problem of $\mathrm{Ni}$ is to use prealloyed steel powders. However, the poor compressibility of the hard prealloyed powder has prohibited its wide application. Another

M.W. WU, Graduate Student, and K.S. HWANG, Professor, are with the Department of Materials Science and Engineering, National Taiwan University, Taipei 106 Taiwan, Republic of China. Contact e-mail: kshwang@ccms.ntu. edu.tw H.S. HUANG, Researcher, is with the Material and Chemical Research Laboratories, Industrial Technology Research Institute, Hsinchu 310 Taiwan, Republic of China.

Manuscript submitted September 11, 2006.

Article published online June 29, 2007. alternative is to employ diffusion-alloyed powders, in which iron powders and alloying elemental powders are diffusion-bonded together at low temperatures. ${ }^{[10]}$ These powders alleviate the segregation problem while maintaining good compressibility. However, the as-sintered microstructure of this powder, while improved, is still not homogeneous, unless extremely long sintering times or high sintering temperatures are employed. For example, in $\mathrm{Fe}-4 \mathrm{Ni}-1.5 \mathrm{Cu}-0.5 \mathrm{Mo}-0.5 \mathrm{C}$ alloys, which are designated by the Metal Powder Industries Federation (MPIF) as FD-0405, many Ni-rich areas are still present when industrial sintering practices are used. ${ }^{[9,11]}$ Moreover, most Ni-rich areas are soft and are located near sintered necks or in pore-rich regions, which are stress concentration sites. Thus, these Ni-rich areas become the most likely crack-initiation sites during mechanical testing and are responsible for the poor mechanical properties of the Ni-containing sintered steels. ${ }^{[11,12,13]}$ Although several studies have correlated the mechanical properties to the pore characteristics and fracture surfaces, ${ }^{[12-15]}$ little direct evidence of the identification of the weak phases has been reported, nor has evidence that links these phases with the mechanical properties. This is possibly because the weak Ni-rich areas are quite small, only a few microns wide, thus making it difficult to perform structure analysis. Moreover, the microstructure is very inhomogeneous and large amounts of pores are present; both of these phenomena also make it difficult to determine the first crack-initiation site.

Despite all of these difficulties, several attempts have been made to determine the role of $\mathrm{Ni}$-rich areas in 
crack initiation and propagation. ${ }^{[12-17]}$ Carabajar et al. reported that the Ni-rich austenite in FD-0408 (Fe-4Ni$0.5 \mathrm{Mo}-1.5 \mathrm{Cu}-0.8 \mathrm{C}$ ) helps impede the propagation of cracks during in-situ tensile tests. ${ }^{[12]}$ Dudrova et al. postulated that the cracks nucleate at the pore edge near the Ni-rich martensite and propagate along the highporosity path in $\mathrm{Fe}-4 \mathrm{Ni}-1.5 \mathrm{Cu}-0.5 \mathrm{Mo}-0.64 \mathrm{C}^{[14]}$ The fatigue behaviors of $\mathrm{Fe}-1.75 \mathrm{Ni}-1.5 \mathrm{Cu}-0.5 \mathrm{Mo}-0.6 \mathrm{C}$ and Fe-1.75Ni-1.5Cu-0.85Mo-0.6C were also examined by Chawla et al. ${ }^{[13,15]}$ They indicated that the Ni-rich areas could impede the propagation of the crack tips. However, other studies of Fe-4Ni-1.5Cu-0.5Mo-0.8C ${ }^{[16]}$ and $\mathrm{Fe}-2 \mathrm{Ni}-0.85 \mathrm{Mo}-0.6 \mathrm{C}^{[17]}$ suggest that the Ni-rich areas enhance the propagation of fatigue cracks. These studies, which show that the fracture behaviors of $\mathrm{Ni}$ containing sintered steels are quite complex, are not conclusive. Nonetheless, they do indicate that Ni-rich areas play an important role in determining the mechanical properties.

The identification of these Ni-rich areas has been inconsistent, as well. Dudrova proposed that the Ni-rich areas in $\mathrm{Fe}-4 \mathrm{Ni}-1.5 \mathrm{Cu}-0.5 \mathrm{Mo}-0.64 \mathrm{C}$ are ferrite, martensite, and austenite. ${ }^{[14]}$ Carabajar et al. indicated that the $\mathrm{Ni}$-rich areas in $\mathrm{Fe}-4 \mathrm{Ni}-1.5 \mathrm{Cu}-0.5 \mathrm{Mo}-0.8 \mathrm{C}$ are martensite and austenite, ${ }^{[12]}$ the same as was reported by Gething et al. for Fe-xNi-0.85Mo-0.4C. ${ }^{[18]}$ Chawla et al. suggested that $\mathrm{Ni}$-rich ferrite, martensite, and other $\mathrm{Ni}$-rich areas are present in $\mathrm{Fe}-1.75 \mathrm{Ni}-1.5 \mathrm{Cu}-0.85 \mathrm{Mo}-0.6 \mathrm{C}$ and Fe-1.75Ni-1.5Cu-0.5Mo-0.6C. ${ }^{[13,15]}$ A more recent study by $\mathrm{Wu}$ et al. reported three different types of $\mathrm{Ni}$-rich areas present in the FD-0405 alloy: ferrite, martensite, and austenite. ${ }^{[11]}$ These reports show that the structure of the Ni-rich areas in Ni-containing powder metal (PM) alloys is still not clear. Moreover, little about either the structural analysis or the detailed methods for phase identification was revealed in these reports.

Thus, the first objective of this study was to directly identify the structure of the Ni-rich areas in the sintered FD-0405 steel, using the electron backscattered diffraction (EBSD) method along with microhardness analysis. The other objective was to perform an in-situ observation of the fracture behavior under a scanning electron microscope (SEM). The purpose was to find out where the crack initiates and how it propagates. The final objective was to propose an effective method to resolve the homogenization problem of $\mathrm{Ni}$, which can then lead to improved mechanical properties.

\section{EXPERIMENTAL PROCEDURE}

The diffusion-alloyed FD-0405 (Fe-4Ni-1.5Cu$0.5 \mathrm{Mo}-0.5 \mathrm{C}$ ) was first used for the study on the evolution of the fracture path. In order to identify the role of $\mathrm{Mo}$ and $\mathrm{Cr}$ in the mechanical properties of Ni-containing PM steels, pure Fe powder and prealloyed $\mathrm{Fe}-1.5 \mathrm{Cr}-0.2 \mathrm{Mo}$, Fe-3Cr-0.5Mo and Fe-1.5Mo powders were used as base powders. The characteristics of these powders are listed in Table I. To prepare the specimens, diffusion-alloyed FD-0405 powders were mixed with 0.6 wt pct graphite powder and 0.75 wt pct ethylene bis-stearamide, which is a lubricant. The powder mixture was compacted into tensile bars as per MPIF standard No. 10. The green density was about $6.85 \mathrm{~g} / \mathrm{cm}^{3}$. The green compacts were heated at $5^{\circ} \mathrm{C} / \mathrm{min}$ to $550{ }^{\circ} \mathrm{C}$ and were held at that temperature for 15 minutes to remove the lubricant. The debound specimens were then sintered at $1120{ }^{\circ} \mathrm{C}$ for 30 minutes or at $1250{ }^{\circ} \mathrm{C}$ for 1 hour, followed by furnace cooling. The furnace cooling rate was about $0.1{ }^{\circ} \mathrm{C} / \mathrm{s}$ at $550{ }^{\circ} \mathrm{C}$. Both debinding and sintering were carried out under an atmosphere of $\mathrm{N}_{2}-9$ pct $\mathrm{H}_{2}$, which had a dew point lower than $-45^{\circ} \mathrm{C}$. All sintered compacts were tempered at $230{ }^{\circ} \mathrm{C}$ for 1 hour.

To prepare the in-situ tensile test specimens, the FD0405 specimens that were sintered at $1120^{\circ} \mathrm{C}$ were used, for this is the sintering temperature most commonly used in the PM industry. Thus, the results obtained could be more valuable for the industry. Furthermore, the microstructures in these specimens were less homogeneous than those of specimens sintered at $1250^{\circ} \mathrm{C}$, which made it easier to identify the crack-initiation sites and to follow the propagation paths under the SEM. Thus, the FD0405 specimens sintered at $1120^{\circ} \mathrm{C}$ were machined into mini tensile bars with the dumbbell contour, using wireelectrical-discharge machining, and then ground to a thickness of about $0.7 \mathrm{~mm}$, using a surface grinder. The dimensions of the specimens are shown in Figure 1. These specimens were further ground using silicon carbide paper and polished using $0.3-\mu \mathrm{m}$ alumina powder suspended in alcohol. The final thickness of the mini tensile bars was controlled to $0.600 \pm 0.046 \mathrm{~mm}$. These specimens were etched using a mixed solution of 4 pct picral and 2 pet Nital. The etched tensile bar was clamped at two ends with a fixture and was placed inside an SEM (model 515, Philips Co., Eindhoven, Holland) for in-situ observation of its fracture behavior under tension. The examination was concentrated at the neck area, which was about $1-\mathrm{mm}$ wide and 2.6- $\mathrm{mm}$ long. About 40 photos of this area were taken at a magnification of between 500 and 1000 times and stored in a computer. As the tensile load increased, photos of the microstructure at the same area were taken and recorded again and then compared to those pictures taken earlier. The strain rate was maintained at $4 \times 10^{-3} / \mathrm{min}$ at the beginning. It was lowered to $1.3 \times 10^{-3} / \mathrm{min}$ when the stress reached about 50 pct of the final tensile strength. Ten specimens were examined, and the results reported are the most typical results from seven specimens. No crack-initiation sites or propagation paths were identified on the other three specimens, because the fracture was fast and was completed before the stress was increased to the next level.

To correlate the in-situ fracture behavior with the microstructure, particularly that near the pores and sintered necks, a field-emission-scanning electron microscope (FE-SEM) (JSM-6500F, JEOL*) equipped with an

*JEOL is a trademark of Japan Electron Optics Ltd., Tokyo.

EBSD system (EBSD, INCA Crystal 300, Oxford Instruments Analytical Ltd., Oxford, United Kingdom) 
Table I. Characteristics of the Steel Powders Used in This Study

\begin{tabular}{|c|c|c|c|c|c|c|}
\hline Composition & $\mathrm{Fe}-4 \mathrm{Ni}-0.5 \mathrm{Mo}-1.5 \mathrm{Cu}$ & $\mathrm{Fe}-1.5 \mathrm{Cr}-0.2 \mathrm{Mo}$ & $\mathrm{Fe}-3 \mathrm{Cr}-0.5 \mathrm{Mo}$ & $\mathrm{Fe}-1.5 \mathrm{Mo}$ & $\mathrm{Fe}$ & $\mathrm{Ni}$ \\
\hline Designation & Distaloy 4800A & $\mathrm{CrL}$ & $\mathrm{CrM}$ & ATOMET 4901 & ASC 100.29 & $\mathrm{Ni}-123$ \\
\hline \multirow[t]{3}{*}{ Particle size, $\mu \mathrm{m}$} & $D_{10}=23.3$ & $D_{10}=27.9$ & $D_{10}=17.7$ & $D_{10}=26.9$ & $D_{10}=30.9$ & $D_{10}=2.4$ \\
\hline & $D_{50}=68.2$ & $D_{50}=63.6$ & $D_{50}=70.9$ & $D_{50}=58.2$ & $D_{50}=61.1$ & $D_{50}=3.7$ \\
\hline & $D_{90}=100.2$ & $D_{90}=115.3$ & $D_{90}=121.1$ & $D_{90}=124.2$ & $D_{90}=126.5$ & $D_{90}=6.9$ \\
\hline $\begin{array}{l}\text { Apparent density, } \\
\mathrm{g} / \mathrm{cm}^{3}\end{array}$ & 3.02 & 2.87 & $\begin{array}{l}2.90 \\
\text { (Hall density) }\end{array}$ & 3.04 & 2.98 & $\begin{array}{l}2.04 \\
\text { (Arnold density) }\end{array}$ \\
\hline $\begin{array}{l}\text { Flow rate, } \mathrm{s} / 50 \mathrm{~g} \\
\text { Composition }\end{array}$ & 27.5 & 26 & 25 & 25.1 & 24 & 一 \\
\hline $\mathrm{Ni}$, wt pet & 3.84 & - & - & - & - & balanced \\
\hline Mo, wt pct & 0.5 & 0.20 & 0.5 & 1.47 & - & - \\
\hline $\mathrm{Cu}$, wt pet & 1.5 & - & - & - & - & - \\
\hline $\mathrm{Mn}$, wt pct & - & - & - & 0.13 & - & - \\
\hline Cr, wt pct & - & 1.50 & 3.0 & - & - & - \\
\hline $\mathrm{C}$, wt pet & 0.003 & 0.002 & 0.003 & 0.003 & 0.002 & 0.079 \\
\hline $\mathrm{O}$, wt pct & 0.13 & 0.16 & 0.21 & 0.080 & 0.08 & 0.208 \\
\hline Supplier & Hoeganaes & Höganäs & Höganäs & QMP & Höganäs & INCO \\
\hline
\end{tabular}

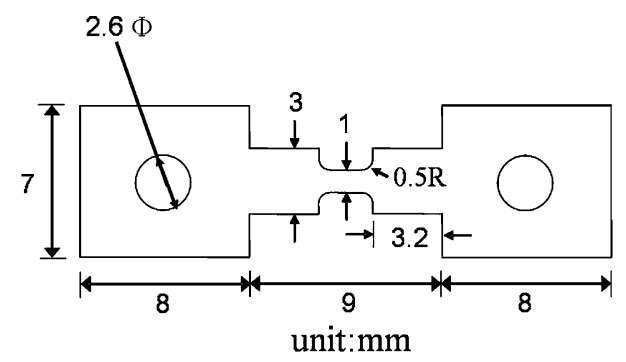

Fig. 1-Dimensions of the in-situ tensile test specimen.

was used to identify the structure of the phases present. The software employed for the analysis was Oxford Instruments INCA 4.06. To ensure good collection of the Kikuchi patterns, which were used to identify the phases, the polished specimens were sputtered for 30 minutes in order to remove the strains in the surface layer. Nonetheless, some residual strains remained and different crystal orientations were present in the microstructure. Thus, different levels of signals were collected for the same phase and were presented in different colors or in different brightness levels in black and white photos.

In addition to the EBSD analysis, the microhardness was also measured at different phases (MVK-E2, Akashi Co., Tokyo). The loading selected was only $10 \mathrm{gf}$ (HV0.01), due to the small size of these Ni-rich areas. The compositions of the different phases were examined using an electron probe microanalyzer (EPMA) (JXA8600SX, JEOL). In order to verify the role of $\mathrm{Cr}$ and Mo in the homogenization of the microstructure and alloying, particularly $\mathrm{Ni}$ and $\mathrm{C}$, the Thermo-Calc program and a TCFE3 database were used to calculate the chemical potential of $\mathrm{C}$ when $\mathrm{Ni}, \mathrm{Cr}$, or $\mathrm{Mo}$ was present in the steel at $1120{ }^{\circ} \mathrm{C}$.

\section{RESULTS}

\section{A. Identification of Ni-Rich Phases}

Figure 2 shows the typical microstructure of the FD0405 sample sintered at $1120{ }^{\circ} \mathrm{C}$. The center of the powder contained mainly pearlite and a small amount of ferrite and bainite. The EPMA analysis indicates that the Mo was distributed uniformly. However, the Ni and $\mathrm{Cu}$ were not; they were mostly present at powder peripheries and in pore-rich regions, as shown in Figure 3. This is because the $\mathrm{Ni}$ was distributed uniformly, first at powder surfaces through surface diffusion; it did not diffuse deep into the iron powder core, however, due to its slow diffusion rate. The copper had a distribution similar to that of $\mathrm{Ni}$. This was because the $\mathrm{Cu}$ could also coat the iron powder uniformly when the $\mathrm{Cu}$ melted at $1083{ }^{\circ} \mathrm{C}$, due to the good wetting between $\mathrm{Cu}$ and $\mathrm{Fe}$. The homogenization of $\mathrm{Cu}$ was incomplete also because of its slow diffusion rate, as compared to that of Mo.

The contents of the $\mathrm{Ni}$ and $\mathrm{Cu}$ in the Ni-rich area at powder surfaces were 4 and $1.5 \mathrm{wt}$ pct, respectively, as measured by EPMA. In contrast, both elements were less than $0.1 \mathrm{wt}$ pct in the core region of the iron powder. The carbon content was not uniform, either. The center region contained higher amounts of carbon compared to the Ni-rich areas at powder surfaces, with a ratio of about $6: 1$. Thus, little lamellae, or featherlike structures, were found at powder surfaces in the Ni-rich/ $\mathrm{C}$-lean areas, while pearlite was found in the center of the powders. To facilitate the discussion on phase

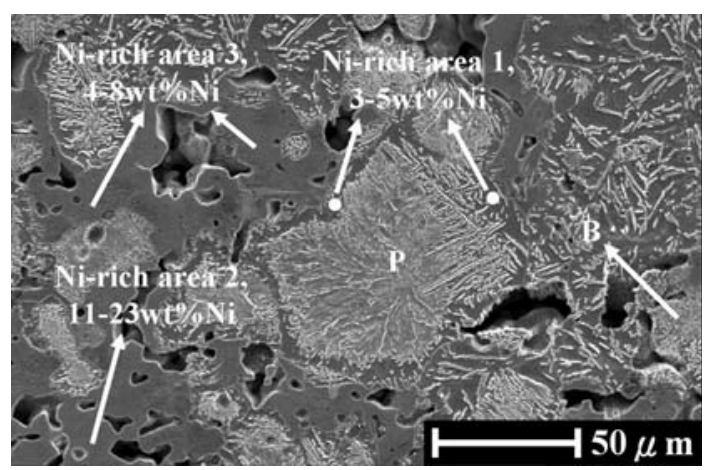

Fig. 2-Microstructure of the FD-0405 compact sintered at $1120^{\circ} \mathrm{C}$ for $30 \mathrm{~min}$ 

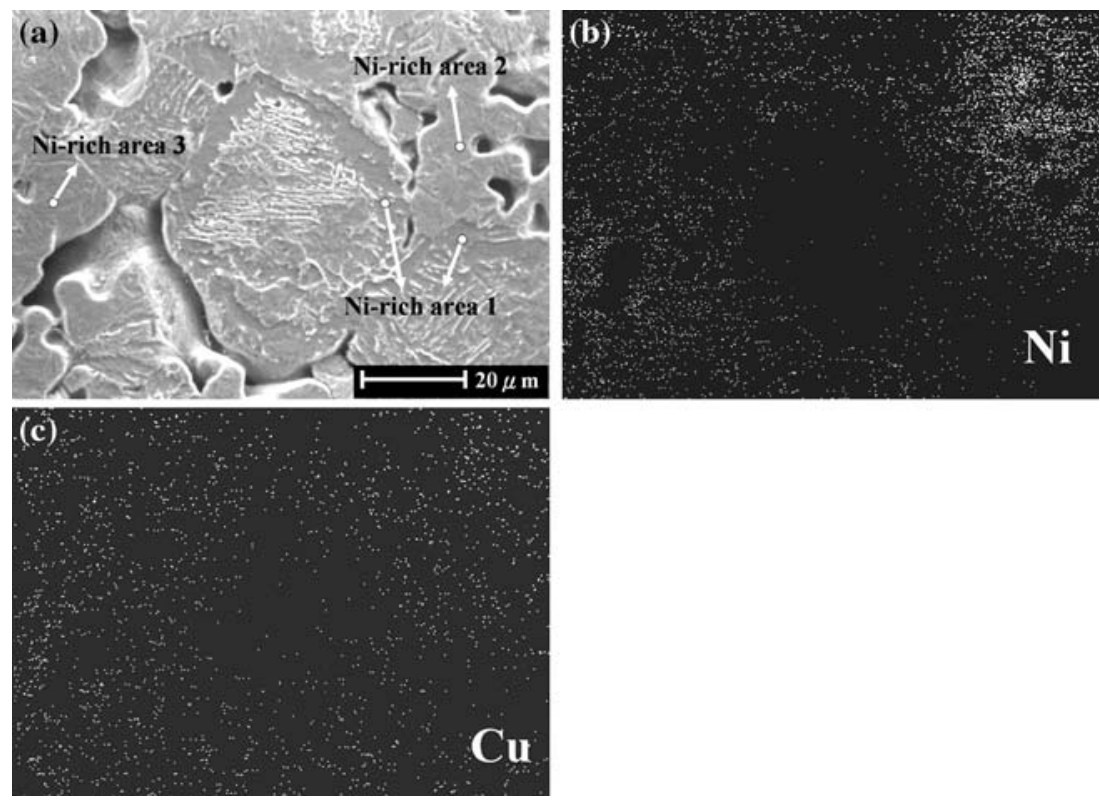

Fig. 3-X-ray mappings of $\mathrm{Ni}$ and $\mathrm{Cu}$ show poor distribution of these two alloying elements in the sintered FD-0405: (a) microstructure, (b) Ni mapping, and (c) $\mathrm{Cu}$ mapping.

identifications, this type of Ni-rich area near the powder surface was designated as Ni-rich area 1. The EBSD analysis further confirmed that Ni-rich area 1 was ferrite, as shown in Figure 4, and the hardness was about HV140, similar to that of the ferrite in wrought steels.

The second type of Ni-rich area, designated as the Nirich area 2, consisted of those areas located at the original Ni powder sites. Despite the fact that Ni had spread out via surface diffusion, the Ni content at the original powder sites was still the highest, between 11 and 23 wt pct, as measured by EPMA. The $\mathrm{Cu}$ content in this area was about $4 \mathrm{wt}$ pct. The hardness was between HV170 and HV260. The EBSD analysis, as shown in Figure 5, indicated that this Ni-rich area was austenite.

The third type of Ni-rich area, as shown in Figure 2, contained a needlelike microstructure and about 4 to 8 wt pet $\mathrm{Ni}$ and 4 wt pet $\mathrm{Cu}$, as measured by EPMA. The hardness was between HV420 and HV562, which was similar to that of the martensite in wrought steels.
This martensite was formed even with a slow furnacecooling rate, because of the high $\mathrm{Ni}$ and $\mathrm{Cu}$ contents and, thus, the high hardenability.

\section{B. Crack Initiation and Propagation}

To identify the crack-initiation sites, mini tensile bars were stressed inside the SEM. As the tensile stress increased to $269 \mathrm{MPa}$, which was about half of the ultimate tensile strength (UTS), cracks started to initiate at the grain boundaries between two adjacent $\mathrm{Ni}$-rich ferrites, as shown in Figures 6(a) and (b). The crack was near the sintered neck and almost perpendicular to the tensile axis. Because this area was quite soft, with a hardness of only HV140, significant plastic deformation occurred ahead of the crack tips, as indicated in Figures 6(c) and (d) by the arrows, when the stress increased to 384 and $402 \mathrm{MPa}$, respectively. This crack propagated slowly along the high-porosity path and eventually fractured the specimen as the applied stress was increased further. This type of primary crack was
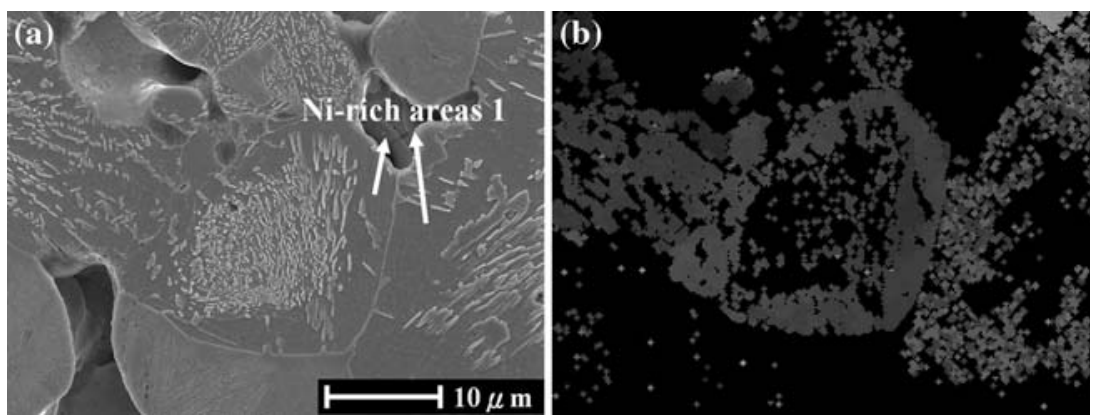

Fig. 4 -EBSD mapping showing ferrite (bright area) in the Ni-rich area 1 (about 4 wt pet Ni, 1.5 wt pet $\mathrm{Cu}$ ) located in the outer region of the powder. 

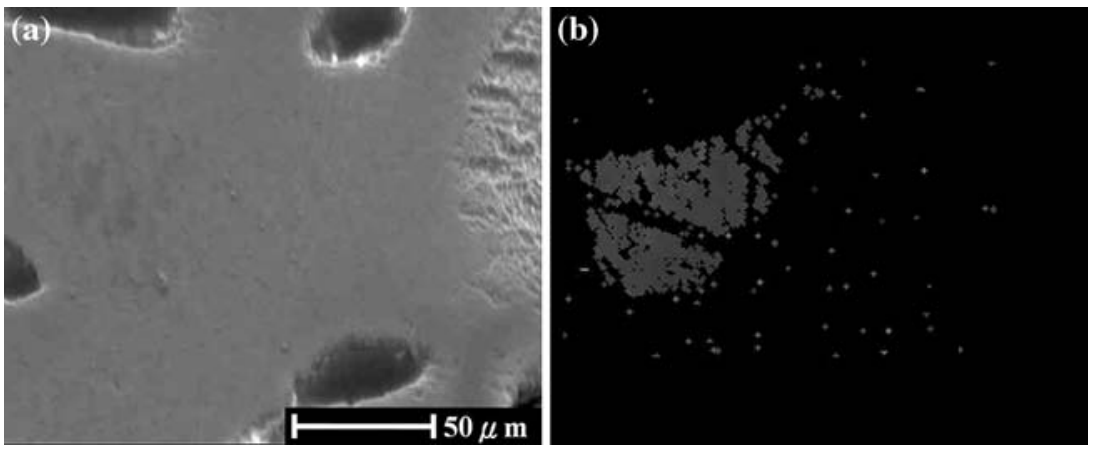

Fig. 5-EBSD mapping showing austenite (bright area) in the Ni-rich area 2 (about 11 to 23 wt pet Ni, 4 wt pet Cu) located in the pore-rich region among particles.
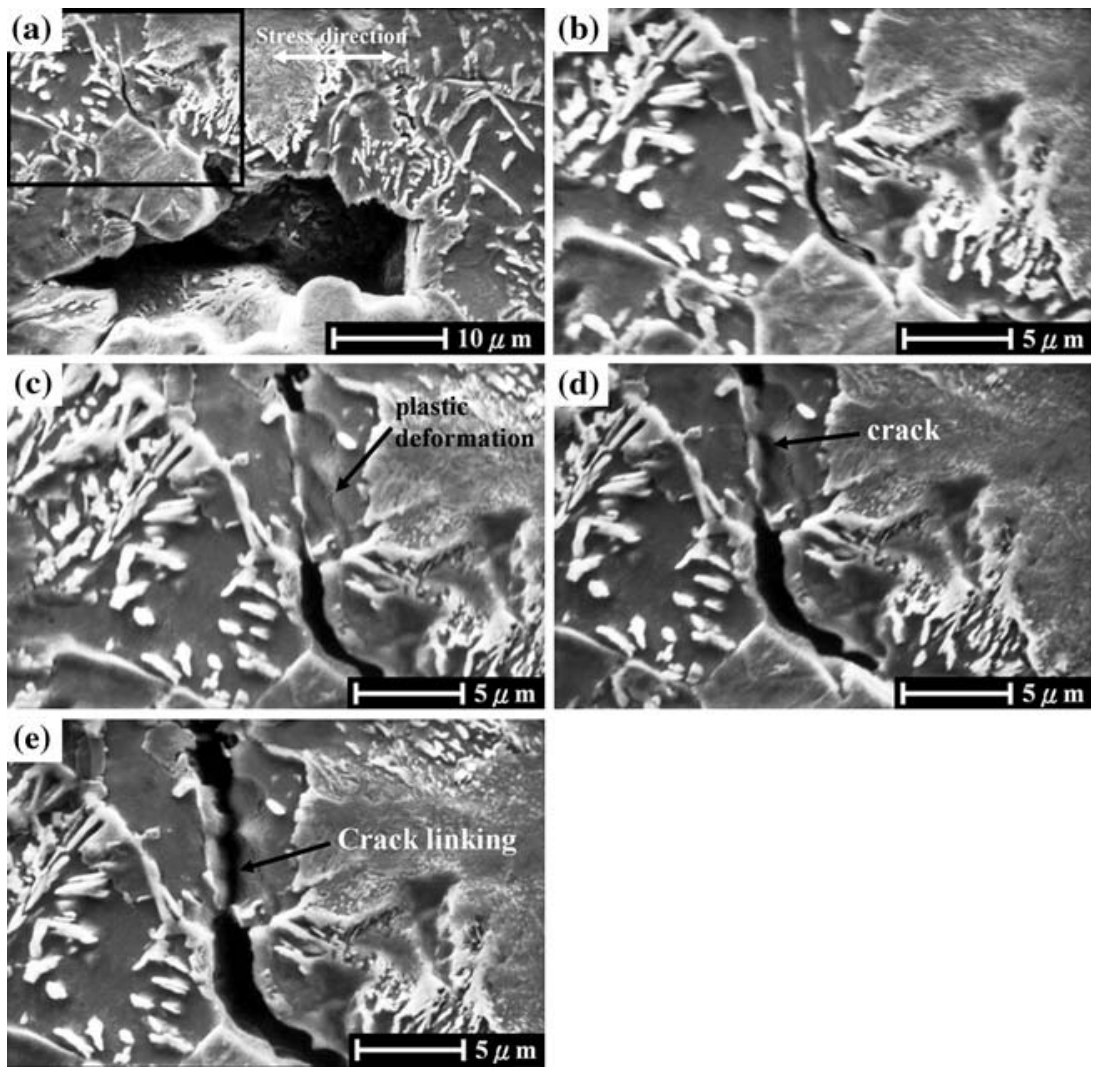

Fig. 6 - Cracks originate from the grain boundary between two Ni-rich ferrite areas that are near the pore and propagate along the grain boundary as the stress increases: (a) 269MPa, (b) 269MPa, (c) 384MPa, (d) 402MPa, (e) $420 \mathrm{MPa}$.

the most frequently seen pattern among the 10 specimens examined.

The second most frequent propagation route that was noticed ran along the interface between two different phases, such as between the pearlite and the Ni-rich ferrite, as shown in Figure 7. This could be attributed to the different hardnesses at the two neighboring phases, which caused dislocation pile-ups at the interface and, thus, the concentration of stress. ${ }^{19]}$ This type of fracture path occurred also at sintered necks or near pores and was related to the Ni-rich ferrite.

The third type of fracture path was a transgranular type, crossing the coarse pearlite inside the iron powder, as shown in Figure 8, particularly when the direction of the cementite was parallel to the stress applied. This fracture pattern occurred at the later stage, when the stress was approaching the UTS. This pattern is similar to the findings of Dollar et al., who pointed out that slip bands in ferrite, which are at an angle of 45 deg toward the stress direction, end at the cementite, as shown in Figure 9, and cause fractures when the stress continues to build up to high levels. ${ }^{[20]}$

These observations suggested that most failures originated at the grain boundaries of Ni-rich ferrite, particularly those near pores and sintered necks, which further decreased the strength of the Ni-rich ferrite, due 

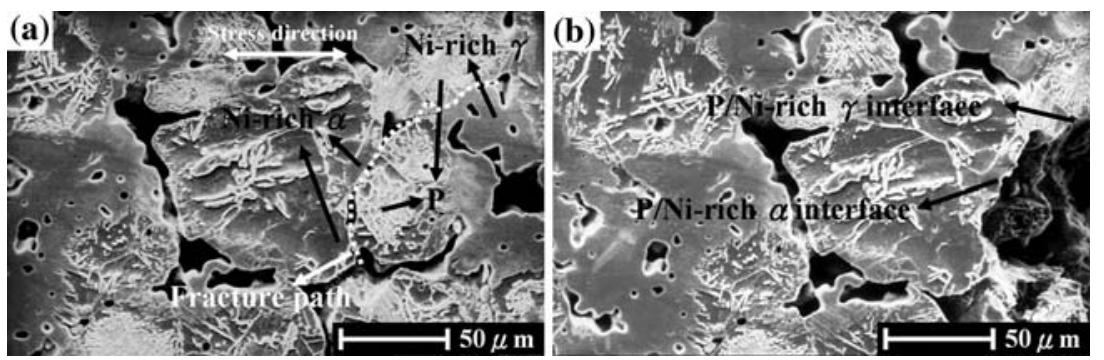

Fig. 7-The second crack path passes through the grain boundary between two different phases, such as between the pearlite and the Ni-rich ferrite: (a) 300MPa, (b) 524MPa (fractured).

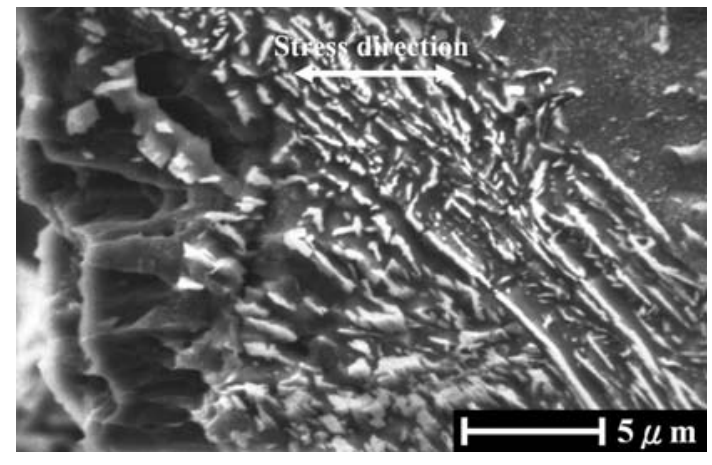

Fig. 8-The third crack path passes through the cementite that is parallel to the direction of the tensile stress: $524 \mathrm{MPa}$.

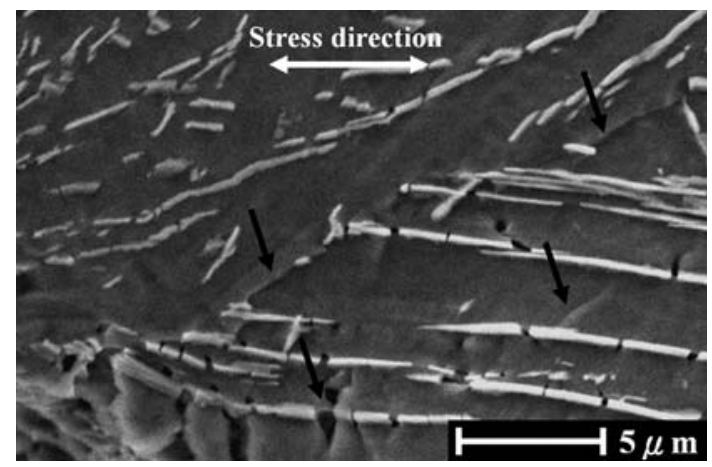

Fig. 9-Intense slip bands indicated by the arrows are inclined at about $45 \mathrm{deg}$ to the tensile axis, which was almost parallel to the cementite.

to the stress concentration effect. No cracks were initiated at the Ni-rich martensite or the Ni-rich austenite, nor at the grain boundaries between them. Thus, the key to improving the mechanical properties of the FD-0405 should be to decrease the amount of Nirich ferrite at the powder peripheries (Ni-rich area 1), the Ni-rich austenite in pore-rich regions (Ni-rich area 2 ), and the pearlite, which is in the center of the powder.

\section{Effect of $\mathrm{Cr}$ and Mo Alloying}

$\mathrm{Wu}$ et al. recently reported that to alleviate the $\mathrm{Ni}$ distribution problem, adding $316 \mathrm{~L}$ stainless steel powder to FD-0405 or using $\mathrm{Fe}-3 \mathrm{Cr}-0.5 \mathrm{Mo}$ prealloyed powder as the base powder could reduce the number of Ni-rich areas, due to the presence of $\mathrm{Cr}^{[11,21]}$ To further examine the effect of $\mathrm{Cr}$ and Mo on alloy homogenization, commercially available prealloyed powders, $\mathrm{Fe}-1.5 \mathrm{Cr}-0.2 \mathrm{Mo}$ and $\mathrm{Fe}-1.5 \mathrm{Mo}$, of which the characteristics are listed in Table I, were used as the base powders. Figure 10 shows the microstructures of the steel compacts with and without the $\mathrm{Cr}$ and $\mathrm{Mo}$ addition. The microstructures of $\mathrm{Fe}-4 \mathrm{Ni}-0.5 \mathrm{C}$ compacts, which were sintered at $1120{ }^{\circ} \mathrm{C}$ and $1250{ }^{\circ} \mathrm{C}$, respectively, were inhomogeneous. After sintering at $1120^{\circ} \mathrm{C}$, the $\mathrm{Fe}-4 \mathrm{Ni}-0.5 \mathrm{C}$ compact contained mainly pearlite, Nirich ferrite, and Ni-rich austenite. The microstructure remained quite inhomogeneous even after sintering at $1250{ }^{\circ} \mathrm{C}$. In contrast, much less Ni-rich ferrite was present in the $\mathrm{Fe}-4 \mathrm{Ni}-1.5 \mathrm{Mo}-0.5 \mathrm{C}$ compacts that were sintered at $1120{ }^{\circ} \mathrm{C}$ and $1250{ }^{\circ} \mathrm{C}$, as shown in Figures 10(c) and (d), respectively. This indicated that the addition of the 1.5 pct Mo helped homogenize the Ni.

The improvement in microstructure due to the addition of $\mathrm{Cr}$ was also observed in the $\mathrm{Fe}-4 \mathrm{Ni}-1.5 \mathrm{Cr}$ $0.2 \mathrm{Mo}-0.5 \mathrm{C}$ compact, as shown in Figures 10 (e) and (f), where no Ni-rich ferrite was found. After sintering at $1250{ }^{\circ} \mathrm{C}$, the microstructure consisted mainly of bainite and martensite, with a little extra fine pearlite in the powder interior. Thus, the UTS of this compact reached $1178 \mathrm{MPa}$, as shown in Table II, without the employment of any accelerated cooling system. When the amount of $\mathrm{Cr}$ and $\mathrm{Mo}$ increased, the amount of martensite further increased, as shown in Figures $10(\mathrm{~g})$ and (h), for the $\mathrm{Fe}-4 \mathrm{Ni}-3 \mathrm{Cr}-0.5 \mathrm{Mo}-0.5 \mathrm{C}$ steel. The microstructures also indicated that the addition of $1.5 \mathrm{Cr}$ or $3 \mathrm{Cr}$ caused pore rounding, which helped alleviate the stress-concentration effect. As a result, the tensile strength increased to $1323 \mathrm{MPa}$ for the compact sintered at $1250{ }^{\circ} \mathrm{C}$. Table II also shows the mechanical properties of the other Ni-containing PM steels reported in the literature. It is evident that the mechanical properties of Ni-containing PM alloys can be improved by increasing the sintering temperature, decreasing the particle size of the Ni powder, and adding $\mathrm{Cr}$ and $\mathrm{Mo}$, which are all related to improving the homogeneity of $\mathrm{Ni}$ and C. ${ }^{[11,12,21,22]}$

The elongations of the Ni-containing PM steels investigated in this study are also included in Table II. In general, an elongation greater than 1 pet was attained. The elongations of the compacts sintered at $1120^{\circ} \mathrm{C}$ are slightly greater than those sintered at $1250{ }^{\circ} \mathrm{C}$, despite the 

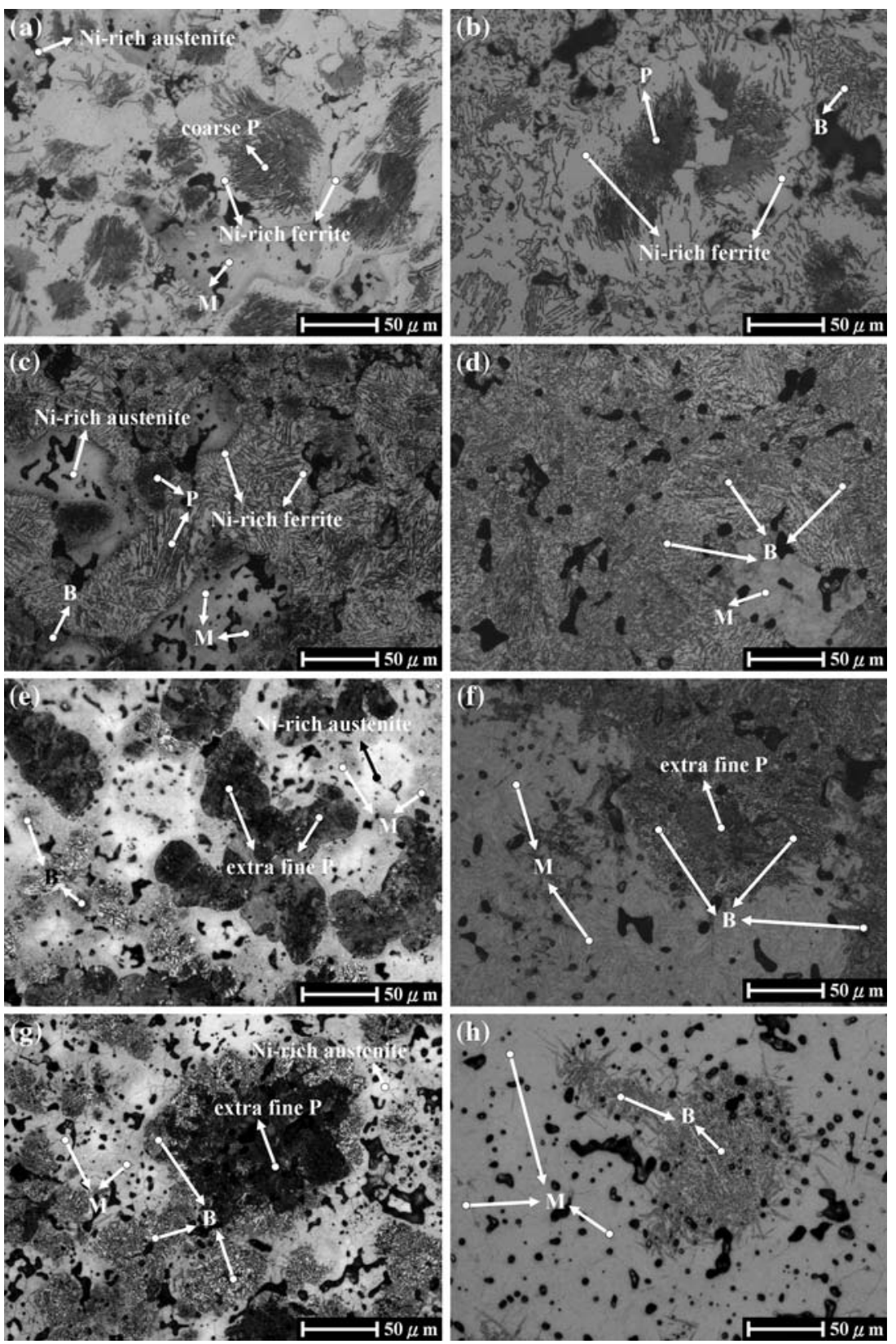

Fig. 10-Microstructures of (a) Fe-4Ni-0.5C compact sintered at $1120{ }^{\circ} \mathrm{C},(b)$ Fe-4Ni-0.5C compact sintered at $1250{ }^{\circ} \mathrm{C},(c)$ Fe-4Ni-1.5Mo-0.5C compact sintered at $1120^{\circ} \mathrm{C},(d) \mathrm{Fe}-4 \mathrm{Ni}-1.5 \mathrm{Mo}-0.5 \mathrm{C}$ compact sintered at $1250{ }^{\circ} \mathrm{C},(e) \mathrm{Fe}-4 \mathrm{Ni}-1.5 \mathrm{Cr}-0.2 \mathrm{Mo}-0.5 \mathrm{C}$ compact sintered at $1120{ }^{\circ} \mathrm{C},(f)$ Fe-4Ni-1.5Cr-0.2Mo-0.5C compact sintered at $1250{ }^{\circ} \mathrm{C}$, (g) Fe-4Ni-3Cr-0.5Mo-0.5C compact sintered at $1120{ }^{\circ} \mathrm{C}$, and $(h)$ Fe-4Ni-3Cr-0.5Mo$0.5 \mathrm{C}$ compact sintered at $1250{ }^{\circ} \mathrm{C}$.

fact that the sintered density was slightly lower and the pore shape was more irregular. The main reason was that there were more soft and ductile ferrite and austenite phases present in the compacts.

\section{DISCUSSION}

\section{A. Fracture Path}

Based on the in-situ observations described previously, the crack-initiation sites and their propagation routes can be illustrated by the schematics shown in
Figure 11. It has been recognized that the sintered neck region is the weakest area, because its load-bearing cross section is the smallest in the compact. This study further shows that most of the neck areas are comprised of Nirich/C-lean ferrites, which are soft. Thus, the Ni-rich ferrite areas become the most vulnerable sites for crack formation. Once these cracks are initiated, they cause plastic deformation in the neighboring region and subsequently form primary cracks. These primary cracks then propagate along grain boundaries or high porosity paths, or cross the coarse pearlite inside the iron powder. 
Table II. Comparison of Processing Conditions and Tensile Strengths of Some PM Steel Compacts Investigated in This Study and by Other Researchers ${ }^{[11,12,21,22]}$

\begin{tabular}{|c|c|c|c|c|c|c|}
\hline Steel Composition ${ }^{[\text {Ref.] }}$ & $\begin{array}{l}\text { Sintering } \\
\text { Temp., }{ }^{\circ} \mathrm{C}\end{array}$ & $\begin{array}{l}\text { Sintered } \\
\text { Density, } \\
\mathrm{g} / \mathrm{cm}^{3}\end{array}$ & $\begin{array}{l}\text { Cooling } \\
\text { Rate, } \\
{ }^{\circ} \mathrm{C} / \mathrm{s}\end{array}$ & $\begin{array}{l}\text { UTS, } \\
\mathrm{MPa}\end{array}$ & $\begin{array}{c}\text { Hardness, Rockwell C } \\
\text { Scale (HRC) or } \\
\text { Rockwell B Scale (HRB) }\end{array}$ & $\begin{array}{c}\text { Elongation, } \\
\text { Pct }\end{array}$ \\
\hline $\mathrm{Fe}-4 \mathrm{Ni}-0.5 \mathrm{C}^{\text {[this study] }}$ & 1120 & 7.11 & 0.1 & 378 & 62 & 3.0 \\
\hline $\mathrm{Fe}-4 \mathrm{Ni}-0.5 \mathrm{C}^{\text {[this study] }}$ & 1250 & 7.24 & 0.1 & 472 & 70 & 2.8 \\
\hline $\mathrm{Fe}-4 \mathrm{Ni}-1.0 \mathrm{Cu}-0.5 \mathrm{C}\left(\mathrm{Ni} \text { powder, } \mathrm{D}_{50}=8 \mu \mathrm{m}\right)^{[22]}$ & 1120 & 7.05 & 1 & 430 & - & - \\
\hline Fe-4Ni-1.0Cu-0.5C (Ni powder, $\left.\mathrm{D}_{50}=1.5 \mu \mathrm{m}\right)^{[22]}$ & 1120 & 7.10 & 1 & 520 & - & - \\
\hline $\mathrm{Fe}-4 \mathrm{Ni}-1.5 \mathrm{Mo}-0.5 \mathrm{C}^{\text {this study] }}$ & 1120 & 7.02 & 0.1 & 650 & 87 & 2.1 \\
\hline $\mathrm{Fe}-4 \mathrm{Ni}-1.5 \mathrm{Mo}-0.5 \mathrm{C}^{\text {this study }]}$ & 1250 & 7.12 & 0.1 & 803 & 92 & 1.8 \\
\hline Fe-4Ni-1.5Cr-0.2Mo- $0.5 \mathrm{C}^{\text {[this study }]}$ & 1120 & 7.10 & 0.1 & 851 & 96 & 1.7 \\
\hline Fe-4Ni-1.5Cr-0.2Mo- $0.5 \mathrm{C}^{\text {[this study] }}$ & 1250 & 7.29 & 0.1 & 1178 & 30 & 1.7 \\
\hline Fe-4Ni-0.5Mo-1.5Cu-0.5C $\mathrm{C}^{[11]}$ & 1120 & 6.85 & 0.1 & 530 & 83 & 2.3 \\
\hline $\mathrm{Fe}-4 \mathrm{Ni}-0.5 \mathrm{Mo}-1.5 \mathrm{Cu}-0.5 \mathrm{C}^{[11]}$ & 1250 & 6.90 & 0.1 & 626 & 91 & 2.0 \\
\hline Fe-4Ni-0.5Mo-1.5Cu-0.5Cr- $0.5 \mathrm{C}^{[11]}$ & 1120 & 6.86 & 0.1 & 603 & 88 & 1.9 \\
\hline $\mathrm{Fe}-4 \mathrm{Ni}-0.5 \mathrm{Mo}-1.5 \mathrm{Cu}-0.5 \mathrm{Cr}-0.5 \mathrm{C}^{[11]}$ & 1250 & 6.93 & 0.1 & 801 & 99 & 1.5 \\
\hline $\mathrm{Fe}-4 \mathrm{Ni}-0.5 \mathrm{Mo}-1.5 \mathrm{Cu}-0.8 \mathrm{C}^{[12]}$ & 1120 & 7.40 & - & 858 & - & 2.4 \\
\hline $\mathrm{Fe}-4 \mathrm{Ni}-3 \mathrm{Cr}-0.5 \mathrm{Mo}-0.5 \mathrm{C}^{[21]}$ & 1120 & 7.05 & 0.1 & 859 & 29 & 1.6 \\
\hline Fe-4Ni-3Cr- $0.5 \mathrm{Mo}-0.5 \mathrm{C}^{[21]}$ & 1250 & 7.23 & 0.1 & 1323 & 39 & 1.8 \\
\hline
\end{tabular}

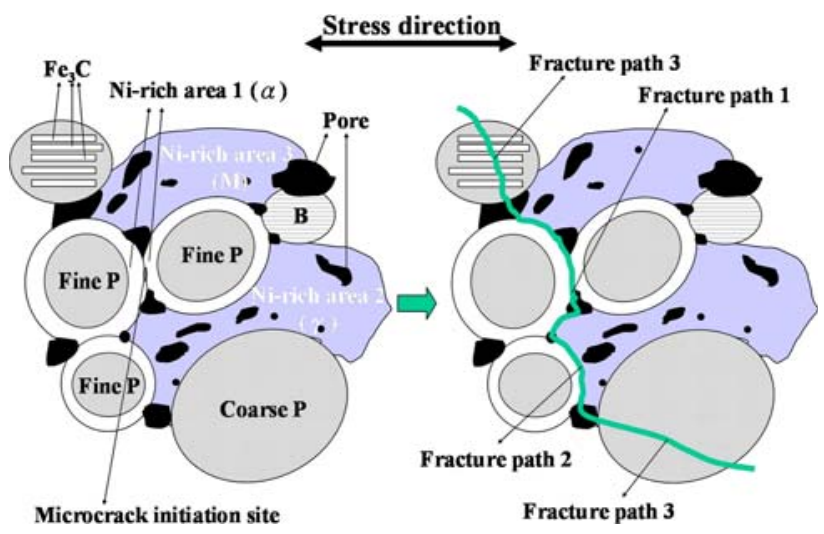

Fig. 11-Schematics of the crack-initiation site and the propagation path of the Fe-4Ni-1.5Cu-0.5Mo-0.5C compacts sintered at $1120^{\circ} \mathrm{C}$.

\section{B. Effect of Alloying with $\mathrm{Cr}$ and Mo Additions}

$\mathrm{Wu}$ et al. reported that the addition of $\mathrm{Cr}$ in the $\mathrm{Ni}$ containing PM alloys could reduce the $\mathrm{Ni}$ content and increase the $\mathrm{C}$ content at powder peripheries while increasing the $\mathrm{Ni}$ and decreasing the $\mathrm{C}$ content in the iron powder cores. This improvement of the homogenization of $\mathrm{Ni}$ and $\mathrm{C}$ reduces the amount of soft Ni-rich areas and improves the mechanical properties. ${ }^{[11,21]}$ The amount and the form of the $\mathrm{Cr}$ introduced also play an important role. Table II shows that using the prealloyed $\mathrm{Fe}-3 \mathrm{Cr}-0.5 \mathrm{Mo}$ powder gives the highest tensile strength, $1323 \mathrm{MPa}$, for the $\mathrm{Fe}-4 \mathrm{Ni}-3 \mathrm{Cr}-0.5 \mathrm{Mo}-0.5 \mathrm{C}$ compact when sintered at $1250{ }^{\circ} \mathrm{C}$ and furnace cooled. This tensile strength, despite the fact that the compact was cooled at a slow cooling rate of $0.1^{\circ} \mathrm{C} / \mathrm{min}$, is the highest reported to date for sinter-hardened PM alloys. When the prealloyed $\mathrm{Fe}-1.5 \mathrm{Cr}-0.2 \mathrm{Mo}$ powder was employed, the strength of the Fe- $4 \mathrm{Ni}-1.5 \mathrm{Cr}-0.2 \mathrm{Mo}-0.5 \mathrm{C}$ decreased to $1178 \mathrm{MPa}$. When the $0.5 \mathrm{wt}$ pct $\mathrm{Cr}$ was introduced in the stainless steel form, the strength of the Fe-4Ni-0.5Cr-0.5Mo- $1.5 \mathrm{Cu}-0.5 \mathrm{C}$ was the lowest, at
$801 \mathrm{MPa} \cdot{ }^{[11]}$ Although the exact compositions of these $\mathrm{Fe}-4 \mathrm{Ni}-\mathrm{xCr}-\mathrm{yMo}-0.5 \mathrm{C}$ alloys were slightly different, the differences suggested that the amount of $\mathrm{Cr}$ and the form of the $\mathrm{Cr}$ addition are the important factors.

The addition of Mo also helped homogenize the microstructure and increase the strength, as shown in Figure 10 and Table II, respectively. But its effect was less significant, compared to that of the addition of $\mathrm{Cr}$.

To understand the reason behind the improved homogenization of alloying and microstructure by adding $\mathrm{Cr}$ and Mo, the Thermo-Calc program was used to calculate the chemical potential of carbon in the steel compacts when $\mathrm{Ni}, \mathrm{Cr}$, and Mo were added. Figure 12 shows that the chemical potential of $\mathrm{C}$ at $1120{ }^{\circ} \mathrm{C}$ increases with increasing Ni content. This means that $\mathrm{C}$ and $\mathrm{Ni}$ have a strong tendency to repel each other. Thus, the carbon content is low in Ni-rich areas, as was observed in this study in Ni-rich ferrite at powder peripheries. This postulation is in agreement with the

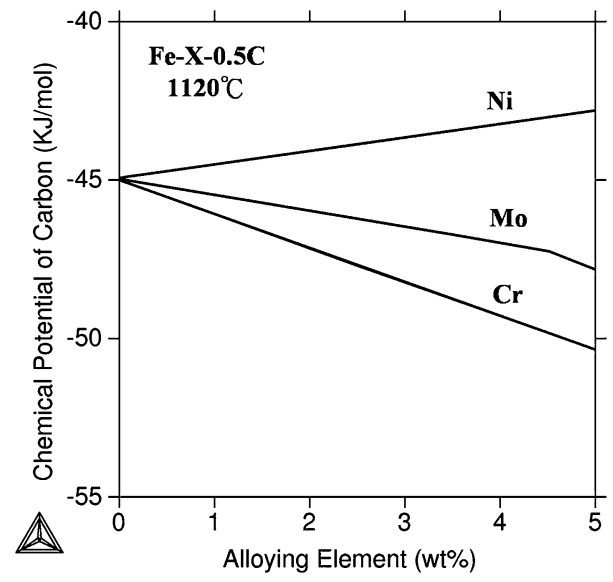

Fig. 12-Chemical potential of carbon in the $\mathrm{Fe}-\mathrm{Ni}-0.5 \mathrm{C}, \mathrm{Fe}-$ Mo-0.5C, and Fe-Cr-0.5C alloys, showing that $\mathrm{Ni}$ and $\mathrm{C}$ have a tendency to repel each other while $\mathrm{Cr}$ and Mo help stabilize the $\mathrm{C}$ in the alloy. 
Table III. The Chemical Potentials of $\mathrm{C}$ in Different Fe-4Ni Alloys, Calculated Using the Thermo-Calc Program

\begin{tabular}{lc}
\hline Steel Composition & $\begin{array}{c}\text { Chemical Potential } \\
\text { of } \mathrm{C}, \mathrm{kJ} / \mathrm{mole}\end{array}$ \\
\hline Fe-4Ni-0.5C & -43.2 \\
Fe-4Ni-1.0Cu-0.5C & -42.7 \\
Fe-4Ni-1.5Mo-0.5C & -44.0 \\
Fe-4Ni-1.5Cr-0.2Mo-0.5C & -45.0 \\
Fe-4Ni-0.5Mo-1.5Cu-0.5C & -42.6 \\
Fe-4Ni-0.5Mo-1.5Cu-0.5Cr-0.5C & -43.1 \\
Fe-4Ni-0.5Mo-1.5Cu-0.8C & -36.0 \\
Fe-4Ni-3Cr-0.5Mo-0.5C & -46.7 \\
\hline
\end{tabular}

findings of Carabajar et al., who added 0.8 wt pet $\mathrm{C}$ in the $\mathrm{Fe}-4 \mathrm{Ni}-1.5 \mathrm{Cu}-0.5 \mathrm{Mo}$ and found coarse pearlite, instead of Ni-rich ferrites, at the sintered necks. ${ }^{[12]}$ The high carbon content of $0.8 \mathrm{wt}$ pct must have compensated for the outward diffusion of $\mathrm{C}$ and thus eliminated the Ni-rich ferrites.

This repulsion effect between $\mathrm{Ni}$ and $\mathrm{C}$, can, however, be reduced when $\mathrm{Cr}$ and Mo are added, as shown in Figure 12. Table III summarizes the chemical potential of $\mathrm{C}$ using the Thermo-Cal program, for all the $\mathrm{Fe}-4 \mathrm{Ni}$ alloys listed in Table II. It demonstrates that the $\mathrm{C}$ is most stable in the $\mathrm{Fe}-4 \mathrm{Ni}-3 \mathrm{Cr}-0.5 \mathrm{Mo}-0.5 \mathrm{C}$ alloy. This suggests that more carbon will be retained in the powder surfaces and more $\mathrm{Ni}$ will diffuse into the powder interior of this alloy. Thus, bainite and martensite will form at the expense of Ni-rich ferrite and Ni-rich austenite, as shown in Figures $10(\mathrm{~g})$ and $(\mathrm{h})$, and the tensile strength can then be much improved.

It should be noted that the improvement in tensile strength due to the $\mathrm{Cr}$ addition might be attributed to the changes in density, pore size, and pore shape. However, previous studies have shown that the tensile strength increases by about 10 pct for every $0.1-\mathrm{g} / \mathrm{cm}^{3}$ increase in density for compacts whose pore shapes and pore sizes are comparable. ${ }^{[5,6,10,23]}$ Thus, the slight increase in sintered density caused by the $\mathrm{Cr}$ addition should not be the main factor behind the significant increase in tensile strength. Previous studies have also shown that when there is an improvement in pore size or pore shape, the elongation should be improved more significantly than the tensile strength. ${ }^{[5,23]}$ Thus, a comparison between the improvement in the elongation and the tensile strength of our specimens should be able to determine whether pore characteristics are crucial factors. However, the data in Table II indicate that the elongations of all the specimens are similar despite the fact that their pore characteristics are different, as shown in Figure 10. This suggests that the pore shape and pore size are not critical factors in determining the elongation of the specimens we examined, not to mention the tensile properties. Moreover, the in-situ fracture examination indicates that no cracks were initiated at the Ni-rich martensite or Ni-rich austenite, or at the grain boundaries between them. This implies that the crack initiation does not depend much on the pore shape or the pore size, but rather on whether the matrix around the pore is Ni-rich ferrite. Thus, replacement of the soft ferrite by martensite or bainite is probably the key solution for improving the tensile properties of Ni-containing PM steels.

It is also possible that the strengthening of the $\mathrm{Cr}$ added steels should be attributed to the solid solutioning. However, the effect of the solid-solutioning strengthening of Mo is larger than that of $\mathrm{Cr}^{[24]}$ Thus, the contribution of $\mathrm{Cr}$ solutioning should not be the main strengthening mechanism, either. It is also noted that the multiplying factor for the hardenability of the compact containing $1.5 \mathrm{Cr}$ and $0.2 \mathrm{Mo}$ is similar to that of the compact containing $1.5 \mathrm{Mo} \cdot{ }^{[25]} \mathrm{But}$ the strength of Fe-4Ni-1.5Cr-0.2Mo-0.5C, at $1178 \mathrm{MPa}$, is $47 \mathrm{pct}$ greater than that of $\mathrm{Fe}-4 \mathrm{Ni}-1.5 \mathrm{Mo}-0.5 \mathrm{C}$, which is $803 \mathrm{MPa}$. Thus, it is less likely that the solid-solution strengthening is the main mechanism behind the increase in tensile strength of the $\mathrm{Cr}$-added $\mathrm{Ni}$ alloys.

These results suggest that the changes in the sintered density, the pore characteristics, or the solid solutioning for Fe cannot improve the 472-MPa strength of the $\mathrm{Fe}-4 \mathrm{Ni}-0.5 \mathrm{C}$ steel and the $803 \mathrm{MPa}$ of the Fe-4Ni$1.5 \mathrm{Mo}-0.5 \mathrm{C}$ steel to the $1178 \mathrm{MPa}$ of the $\mathrm{Fe}-4 \mathrm{Ni}-1.5 \mathrm{Cr}-$ $0.2 \mathrm{Mo}-0.5 \mathrm{C}$ steel. The improvement in $\mathrm{Ni}$ and $\mathrm{C}$ homogenization, which is caused by the $\mathrm{Cr}$ addition, is most likely the key factor in the improvement of the tensile strength in Ni-containing PM steels.

\section{CONCLUSIONS}

Most studies of the fracture behavior of sintered Nicontaining steels have focused on the macroscopic characteristics of the pores and the phases present in the compact. However, their microscopic role on the crack initiation and propagation has been neglected. In this study, tensile tests were conducted on sintered FD0405 (Fe-4Ni-1.5Cu-0.5Mo-0.5C) steels inside an SEM. The in-situ SEM observations indicate that most cracks initiate at the grain boundaries between the Ni-rich ( 4 pct $\mathrm{Ni}$ and $1.5 \mathrm{pct} \mathrm{Cu}$ ) areas, which are near the sintered necks or pores and perpendicular to the direction of the loading. This Ni-rich area is lean in carbon and the hardness is low, between HV140 and HV160. These areas have been verified as ferrites using the EBSD analysis method.

To improve the mechanical properties of the $\mathrm{Ni}$ containing PM steels, the elimination of the soft Ni-rich ferrite is essential. This can be achieved by adding $\mathrm{Cr}$ or $\mathrm{Mo}$, with $\mathrm{Cr}$ being preferred. With Fe-1.5Cr-0.2Mo and $\mathrm{Fe}-3 \mathrm{Cr}-0.5 \mathrm{Mo}$ prealloyed powder as the base materials, the Ni-rich ferrite in the sintered compact is eliminated and replaced by bainite or martensite. The as-sintered and tempered compact can achieve tensile strengths of 1178 and $1323 \mathrm{MPa}$, respectively, which are the highest numbers reported to date for sinter-hardened PM alloys.

This beneficial effect of the $\mathrm{Cr}$ addition was attributed to the reduction of the repulsion effect between $\mathrm{Ni}$ and C. The thermodynamic analysis using the Thermo-Calc program indicates that the $\mathrm{Cr}$ addition could reduce the chemical potential of $\mathrm{C}$. As a result, more $\mathrm{C}$ can be retained in the Ni-rich areas at powder surfaces, while more $\mathrm{Ni}$ can be contained in the powder interior. Thus, the Ni-rich/C-lean ferrites, which are the most 
vulnerable sites for crack initiation, are eliminated and replaced by bainite and martensite.

\section{ACKNOWLEDGMENT}

The authors thank the Lenco Co. and the National Science Council for their support of this project, under Contract No. NSC 94-2622-E-002-008-CC3.

\section{REFERENCES}

1. F. Thümmler and R. Oberacker: Introduction to $P M$, The Institute of Materials, London, UK, 1993, pp. 255-58.

2. N. Chawla and X. Deng: Mater. Sci. Eng., 2005, vol. 390A, pp. $98-112$.

3. W.A. Spitzig, R.E. Semlser, and O. Richmond: Acta Metall., 1988, vol. 36 (5), pp. 1201-11.

4. R.J. Bourcier, D.A. Koss, R.E. Smelser, and O. Richmond: Acta Metall., 1986, vol. 34 (12), pp. 2443-53.

5. K.M. Vedula and R.W. Heckel: in Modem Developments in Powder Metallurgy, H.H. Hausner, H.W. Antes and G.D. Smith, eds., Vol. 12, Metal Powder Industries Federation, Princeton, NJ 1981, pp. 759-77.

6. T. Marcu, A. Molinari, G. Straffelini, and S. Berg: Powder Metall., 2005, vol. 48 (2), pp. 139-43.

7. M. Hanada, N. Motooka, and T. Honda: Advances in Powder Metallurgy and Particulate Materials, compiled by J.M. Capus and R.M. German, MPIF, Princeton, NJ, 1992, vol. 5, pp. 215-26.

8. R. J. Causton: Advances in Powder Metallurgy and Particulate Materials, compiled by T.M. Cadle and K.S. Narasimhan, MPIF, Princeton, NJ, 1996, vol. 4, part 13, pp. 391-412.
9. M. Khaleghi and R. Haynes: Powder Metall., 1985, vol. 28 (4), pp. 217-23.

10. Materials Standards for $P / M$ Structural Parts, Metal Powder Industries Federation, Princeton, NJ, 2003, pp. 42-49.

11. M.W. Wu, K.S. Hwang, H.S. Huang, and K.S. Narasimhan: Metall. Mater. Trans. A, 2006, vol. 37A, pp. 2559-68.

12. S. Carabajar, C. Verdu, and R. Fougeres: Mater. Sci. Eng., 1997, vol. 232A, pp. 80-87.

13. N. Chawla, T.F. Murphy, K.S. Narasimhan, M. Koopman, and K.K. Chawla: Mater. Sci. Eng., 2001, vol. 308A, pp. 180-88.

14. E. Dudrova, M. Kabatova, and M. Kupkova: Kov. Mater., 2002, vol. 40, pp. 24-33.

15. S.J. Polasik, J.J. Williams, and N. Chawla: Metall. Mater. Trans. A, 2002, vol. 33A, pp. 73-81.

16. S. Carabajar, C. Verdu, A. Hamel, and R. Fougeres: Mater. Sci. Eng., 1998, vol. 257A, pp. 225-34.

17. N. Chawla, S. Polasik, K.S. Narasimhan, T. Murphy, M. Koopman, and K.K. Chawla: Int. J. Powder Metall., 2001, vol. 37 (3), pp. 49-57.

18. B.A. Gething, D.F. Heaney, D.A. Koss, and T.J. Mueller: Mater. Sci. Eng., 2005, vol. 390A, pp. 19-26.

19. Z.R. He, G.X. Lin, and H.A. Chen: Mater. Sci. Eng., 2001, vols. 319A-321A, pp. 312-15.

20. M. Dollar, I.M. Bernstein, and A.W. Thompson: Acta Metall., 1988, vol. 36 (2), pp. 311-20.

21. M.W. Wu and K.S. Hwang: Metall. Mater. Trans. A, 2006, vol. 37A, pp. 3577-85.

22. S.T. Campbell, T. Singh, and T.F. Stephenson: Advances in Powder Metallurgy and Particulate Materials, compiled by W.B. James and R.A. Chernenkoff, MPIF, Princeton, NJ, 2004, part 7, pp. $105-15$.

23. H. Danninger, D. Spoljaric, and B. Weiss: Int. J. Powder Metall., 1997, vol. 33 (4), pp. 43-53.

24. W.F. Smith: Structure and Properties of Engineering Alloys, 2 ed., McGraw-Hill Co, New York, NY, 1993, pp. 136-37.

25. A. Moser and A. Legat: Hart. Techn. Mitt., 1969, vol. 24 (2), pp. $100-05$. 